\title{
Cover crops for reniform nematode suppression in cotton: greenhouse and field evaluations
}

\author{
Guilherme L. Asmus ${ }^{1}$, Mário M. Inomoto² \& Roseane A. Cargnin ${ }^{3}$ \\ ${ }^{1}$ Embrapa Agropecuária Oeste, Cx. Postal 661, 79804-970, Dourados, MS, Brazil; ${ }^{2}$ Departamento de Entomologia, Fitopatologia \\ e Zoologia Agrícola, ESALQ, Universidade de São Paulo, Piracicaba, SP, Brazil; ${ }^{3}$ Departamento de Agronomia, Universidade \\ Federal de Mato Grosso do Sul, 79804-970, Dourados, MS, Brazil
}

Corresponding author: Guilherme L. Asmus, e-mail: asmus@cpao.embrapa.br

\begin{abstract}
Two greenhouse and one field experiment were carried out to evaluate the reaction of cover crops to reniform nematode, Rotylenchulus reniformis, and their effect on nematode populations in a naturally infested soil $\left(2,359\right.$ nematodes $\left./ 200 \mathrm{~cm}^{3}\right)$ and on cotton yield. Oil radish (Raphanus sativus), Mulato grass (Brachiaria ruziziensis x B. brizantha), forage sorghum (Sorghum bicolor), tef (Eragrostis tef), foxtail millet (Setaria italica), Algerian (Avena byzantina) and black (A. strigosa) oats, pearl millet (Pennisetum glaucum), and finger millet (Eleusine coracana) were determined to be poor hosts for $R$. reniformis in greenhouse experiments. Grain amaranth (Amaranthus cruentus) and quinoa (Chenopodium quinoa) were good hosts to $R$. reniformis. In the field, lower nematode densities were observed after Mulato grass, oil radish and forage sorghum. Higher cotton fiber yields were obtained from plots cultivated with Mulato grass or sorghum during the winter compared to clean fallow. Cotton yield was inversely correlated with both reproduction factor $(\mathrm{p}<0.05)$ of the nematode on the winter cover crops and population of $R$. reniformis at cotton planting $(\mathrm{p}<0.01)$.
\end{abstract}

Keywords: Gossypium hirsutum, nematode management, no-till cropping system, Rotylenchulus reniformis.

\section{RESUMO}

Culturas de cobertura para o manejo do nematóide reniforme em algodoeiro: avaliações em casa de vegetação e campo

Foram realizados dois experimentos em casa de vegetação e um experimento em campo, com o objetivo de avaliar a reação de culturas de cobertura ao nematóide reniforme, Rotylenchulus reniformis, e seu efeito sobre a população do nematóide em uma área naturalmente infestada (2.359 nematóides $\left./ 200 \mathrm{~cm}^{3}\right)$ e sobre a produção de algodão. As culturas de nabo forrageiro (Raphanus sativus), capim-mulato (Brachiaria ruziziensis x B. brizantha), sorgo forrageiro (Sorghum bicolor), tef (Eragrostis tef), capim-moa (Setaria italica), aveias amarela (Avena byzantina) e preta (A. strigosa), milheto (Pennisetum glaucum) e capim-pé-de-galinha (Eleusine coracana) comportaram-se como maus hospedeiros de $R$. reniformis nos experimentos em casa de vegetação. Amaranto (Amaranthus cruentus) e quinoa (Chenopodium quinoa) foram bons hospedeiros de $R$. reniformis. No campo, as menores densidades dos nematóides foram observadas nas parcelas onde foram cultivados capim-mulato, nabo forrageiro e sorgo forrageiro. As maiores produtividades de fibra de algodão foram obtidas nas parcelas cultivadas durante o outono e inverno com capim-mulato ou sorgo forrageiro, quando comparadas com aquelas que permaneceram em alqueive. A produtividade de algodão correlacionou-se negativamente com o fator de reprodução do nematóide nas culturas de cobertura $(\mathrm{P}<0,05)$ e com a população de $R$. reniformis no plantio de algodão $(\mathrm{P}<0,01)$.

Palavras-chave: Gossypium hirsutum, manejo de nematóides, sistema plantio direto, Rotylenchulus reniformis.

\section{INTRODUCTION}

The reniform nematode (Rotylenchulus reniformis Linford \& Oliveira, 1940) is a major plant-parasitic nematode of cotton worldwide (Starr, 1998), especially in the USA, where it is widely distributed. Reniform nematode is also becoming a very important pathogen in Brazil, being found in almost all important cotton growing areas in the central region of the country (Asmus, 2004). Due to the limited knowledge about non-host plants for crop rotation and resistant cotton cultivars (Robinson et al., 1997; Robinson, 2002), its management has been restricted to the use of nematicides, whose detrimental effects on the environment are well known. The use of cotton cultivars more tolerant to $R$. reniformis, and spring or autumn crop rotations with non-hosts to this nematode have minimum impact on the environment, and should be encouraged.

In the absence of host plants and/or under adverse climatic conditions, nematode populations in soil tend to decrease (McSorley, 1998). Therefore, overwinter fallow with weed control (clean fallow) should contribute to nematode management. However, in a no-tillage cropping system, the soil is kept covered by one or more crops during autumn and winter seasons, a condition that is particularly important in tropical areas with high temperature and low rainfall in winter, such as in the Brazilian Central Region 
(Salton et al., 2001). Depending on the susceptibility of the cover crops used locally, $R$. reniformis populations can increase and reach damaging levels to crops planted the following season (Gallaher et al., 1988; Jones \& McLean, 2004). Approximately 13.5 million hectares have been cultivated under the no-tillage system in Brazil (Oliveira \& Veiga Filho, 2002), and pearl millet represents the main cover crop used (Zancanaro \& Tessaro, 2006). Other plant species including amaranth (Amaranthus cruentus), quinoa (Chenopodium quinoa), forage sorghum (Sorghum bicolor and S. bicolor x S. sudanense) and several annual or perennial grasses have also been tested as cover crops (Spehar \& Santos, 2002; Spehar et al., 2003; Lamas, 2007). However, their susceptibility to $R$. reniformis was not known. The objectives of this work were: 1) to evaluate the ability of selected plant species potentially suitable for cover crops for suppression of reniform nematode under greenhouse conditions and, 2) to evaluate the effect of these cover crops on soil populations of $R$. reniformis and on cotton yield under field conditions.

\section{MATERIAL AND METHODS}

Two greenhouse and one field experiment were carried out from September 2003 to April 2005. The greenhouse experiments were located at Embrapa Agropecuária Oeste, in Dourados, Mato Grosso do Sul State, Brazil. The field experiment was conducted in a cotton field naturally infested with $R$. reniformis $\left(2,359\right.$ nematodes $/ 200 \mathrm{~cm}^{3}$ soil), in Aral Moreira, Mato Grosso do Sul State, Brazil.

\section{Greenhouse Experiments}

Host status for $R$. reniformis of 12 cover crop species was evaluated in Experiment 1. The tested plants were grain amaranth (Amaranthus cruentus 'BRS Alegria'), two cultivars of black oat (Avena strigosa 'Embrapa 140' and 'Common'), finger millet [Eleusine coracana 'Agronorte'], two cultivars of forage sorghum [Sorghum bicolor 'Santa Elisa 38' and 'IPA 7301011'], foxtail millet (Setaria italica), oil radish (Raphanus sativus var. oleiferus 'Siletina'), pearl millet (Pennisetum glaucum 'BRS 1501'), two cultivars of quinoa (Chenopodium quinoa 'BRS Piabiru' and 'Common'), and tef (Eragrostis tef). French marigold (Tagetes patula) was included as a resistant control, according to Caswell et al. (1991). Three seeds of each plant species were sown in $500-\mathrm{cm}^{3}$ pots containing $400 \mathrm{~cm}^{3}$ of sterilized substrate $(58.5 \%$ sand, $7 \%$ silt and $34.5 \%$ clay) and the seedlings were thinned to one per pot prior to nematode inoculation.

$R$. reniformis inoculum used in experiment 1 was originally collected from soybean roots (Glycine max) and multiplied for 90 days on castor roots (Ricinus communis) in the greenhouse. Eggs and larvae of $R$. reniformis were extracted from castor roots using the blender-sieving method followed by sucrose centrifugation (Coolen \& D'Herde, 1972) one day before nematode inoculation. Inoculum of 1,216 eggs and larvae was distributed into two holes about $3.0 \mathrm{~cm}$ deep and 1.0 $\mathrm{cm}$ from the plant stem. Final population $(\mathrm{Pf})$ of $R$. reniformis was estimated 60 days after inoculation. Nematodes were extracted from the roots (Coolen \& D'Herde, 1972) and from the substrate (Jenkins, 1964), and the reproductive factor (RF = $\mathrm{Pf} / \mathrm{Pi})$ calculated.

In a second experiment (Experiment 2), the tested plants were black oat ( $A$. strigosa 'Embrapa 29'), Mulato grass (Brachiaria ruziziensis x B. brizantha), Algerian oat ( $A$. byzantina 'São Carlos'), oil radish 'Siletina', pear millet 'BRS 1501' and forage sorghum 'Santa Elisa 38'. Soybean 'BR 9625619' and French marigold were included as standard good and poor hosts, respectively. Approximately 1,000 eggs + larvae of $R$. reniformis were inoculated per pot. Sixty days after inoculation, nematodes were extracted from roots and soil using the same procedures as in Experiment 1.

Both experiments were arranged in a completely randomized design with eight (experiment 1) or six (experiment 2) replications. Each experimental unit consisted of a plastic pot with one plant. Data on nematode reproductive factor were $\log$ transformed $[\log (\mathrm{x}+1)]$ prior to analysis of variance, and treatments were compared using LSD test.

\section{Field Experiment}

As forage sorghum 'Santa Elisa 38', Mulato grass, pearl millet 'BRS 1501', and oil radish 'Siletina' responded as poor hosts of $R$. reniformis in greenhouse experiments and are species very well adapted for the Central Region of Brazil, they were also included in a subsequent field experiment designed to determine their influence on $R$. reniformis population density and on cotton production. Clean fallow (with manual weed control) was included as $R$. reniformis negative control treatment.

The experiment was carried out between April 2004 and April 2005 at a commercial farm located in Aral Moreira, Mato Grosso do Sul State, Brazil (S22 54 '54" W055'31'39", annual average temperature of $25^{\circ} \mathrm{C}$ and $1,687 \mathrm{~mm}$ annual average rainfall). The experimental design was a completely randomized block with five replications. Each experimental plot was $50 \mathrm{~m}^{2}$ in size. Cover crops were established immediately after mechanical destruction of crop residues following cotton harvest. On 29 April 2004, cover crops were sown manually in rows $0.40 \mathrm{~m}$ apart. The amount of seeds planted was $10 \mathrm{~kg} \cdot \mathrm{ha}^{-1}$ (forage sorghum and Mulato grass), 15 kg.ha-1 (pearl millet), and $3 \mathrm{~kg} \cdot \mathrm{ha}^{-1}$ (oil radish). Cover crops were grown for six months, and precipitation was recorded. Weeds were managed manually. On 22 October 2004, cover crops were sprayed with glyphosate $\left(3.0 \mathrm{~kg}\right.$ a.i.ha $\left.{ }^{-1}\right)$, and on 9 November 2004 cotton 'Delta Opal' was sown directly over the crop residues in eight rows, $0.80 \mathrm{~m}$ apart, in each plot. Cultural practices followed local recommendations for no-till practice. On 4 April 2005, all bolls of the two $5.0 \mathrm{~m}$-long central rows were harvested. Lint percentage and boll weight were estimated based on 20 bolls from each plot.

Soil population of $R$. reniformis was determined from a pooled sample consisting of eight soil cores (20$\mathrm{cm}$ depth) taken at random from each plot. Soil samples were collected on 29 April 2004 (just prior to cover crops 
sowing; initial population $=\mathrm{P} 1$ ), and on 9 November 2004 (at cotton sowing; population after cover crops = P2). A 200$\mathrm{cm}^{3}$ subsample from each pooled sample was processed for nematode extraction using sieving and centrifugal flotation (Jenkins, 1964). Roots were sampled from four cotton plants in each plot at flowering (11 January 2005; P3) and the nematodes extracted (Coolen \& D'Herde, 1972). After counting, the number of nematodes (eggs and vermiform stages) per gram of root was calculated. Nematodes extracted were fixed by heating the suspension to $55^{\circ} \mathrm{C}$ for five minutes and were then kept in $2 \%$ formalin. Numbers of nematodes were estimated in Peters' counting slide under microscope. Changes in $R$. reniformis population after cover crops (RFC) were estimated by $\mathrm{RFC}=\mathrm{P} 2 / \mathrm{P} 1$. Nematode counts were $\log$-transformed $(\log (\mathrm{x}+1))$ prior to analysis of variance (ANOVA). Means of treatments were compared using LSD test. RFC, P2, and the number of nematodes/ $g$ of roots were correlated with seed cotton yield using Pearson's correlation analysis.

\section{RESULTS AND DISCUSSION}

\section{Greenhouse Experiments}

All cover crops tested were poor hosts for R.reniformis, except grain amaranth and quinoa, which resulted in RF $>1$ (Table 1). The highest RF was observed on grain amaranth

TABLE 1 - Reproduction factor $(\mathrm{RF})^{1}$ of Rotylenchulus reniformis on cover crops under greenhouse conditions

\begin{tabular}{lcc}
\hline \hline Cover crop & Experiment 1 & Experiment 2 \\
\hline Soybean 'BR 96-25619 & - & $16.50 \mathrm{a}$ \\
Grain amaranth 'BRS Alegria' & $6.68 \mathrm{a}$ & - \\
Quinoa 'BRS Piabiru' & $4.59 \mathrm{~b}$ & - \\
Quinoa 'Common' & $3.89 \mathrm{c}$ & - \\
French marigold & $0.79 \mathrm{~d}$ & $0.31 \mathrm{~b}$ \\
Mulato grass & - & $0.09 \mathrm{c}$ \\
Tef & $0.67 \mathrm{~d}$ & - \\
Oil radish 'Siletina' & $0.21 \mathrm{e}$ & $0.13 \mathrm{bc}$ \\
Forage sorghum 'Santa Elisa 38' & $0.14 \mathrm{e}$ & $0.08 \mathrm{c}$ \\
Forage sorghum 'IPA 7301011' & $0.12 \mathrm{e}$ & - \\
Foxtail millet & $0.12 \mathrm{e}$ & - \\
Black oat 'Embrapa 29' & - & $0.04 \mathrm{c}$ \\
Black oat 'Embrapa 140' & $0.12 \mathrm{e}$ & - \\
Black oat 'Common' & $0.10 \mathrm{e}$ & - \\
Algerian oat 'São Carlos' & - & \\
Pearl millet 'BRS 1501' & $0.09 \mathrm{e}$ & $0.04 \mathrm{c}$ \\
Finger millet 'Agronorte' & $0.08 \mathrm{e}$ & - \\
CV(\%) & 33,31 & 30,68 \\
\hline
\end{tabular}

${ }^{1} \mathrm{RF}=$ Final $(\mathrm{Pf}) /$ Initial $(\mathrm{Pi})$ population; $\mathrm{Pi}=1,216$ nematodes/plant (experiment 1) and 1,000 nematodes/plant (experiment 2)

Means are average of eight (experiment 1) or six (experiment 2) replications. Data followed by the same letter were not different according to LSD test at $\mathrm{P}=0.05$ based on $\log (\mathrm{x}+1)$ transformed values.
'BRS Alegria', followed by the two cultivars of quinoa. Thus, these plant species should not be used as cover crops in areas infested with the reniform nematode. Host status of these plant species for $R$. reniformis had not been evaluated before. Previously, Lal et al. (1976) evaluated the host status of species of Amaranthus and Chenopodium and rated Chenopodium murale as good host, Amaranthus spinosus as poor host, and A. viridis and C. album as non-hosts to $R$. reniformis based on the number of egg-masses and young females per plant. Therefore, host status of Amaranthus and Chenopodium for $R$. reniform is species-dependent.

Robinson et al. (1997) listed host status of $R$. reniformis on 364 plant species tested, and 314 of them showed contradictory host status, such as that shown by Sorghum bicolor. Our results showed that both forage sorghum cultivars tested are poor hosts for the nematode. Thus, the host status of sorghum cultivars should be characterized prior to their use as cover crops in $R$. reniformis-infested fields. Our results confirm previous findings that oats and oil radish are poor hosts of $R$. reniformis (Birchfield \& Brister 1962; Hutchinson et al., 2003; Jones \& McLean, 2004). Interestingly, all tested monocots rated as poor host species in our study. This is in agreement with the findings of Ferraz (1985) and the previously mentioned paper. Monocots, especially gramineous species, should be the main crops to be used as rotational or cover crops in $R$. reniformis-infested areas.

\section{Field Experiment}

Precipitation during the six months that cover crops were grown was $863 \mathrm{~mm}$. All cover crop species established very well with sufficient plant residues for no-till practice. The emergence of cotton was markedly reduced in plots where oil radish had been grown during the winter. For this reason we did not use data from those plots for yield assessment. Allelopathic effects of several Brassicaceae on both cotton germination and vigor were reported by Haramoto \& Gallandt (2005). As oil radish proved to have beneficial effects in reducing $R$. reniformis soil populations during winter, further studies to investigate the time needed between burning down oil radish and sowing cotton are urgently needed. In general, there were significant $(\mathrm{P}<0.05)$ differences among treatments after cover crops (P2) and in the middle season of cotton roots (P3) (Table 2). Since there were significant differences in initial populations (P1), the effect of treatments on $R$. reniformis populations was better characterized by the RFC.

Due to the absence of hosts, clean fallow led to a natural decline of $R$. reniformis during winter (Table 2), as was also observed by Sharma et al. (1996). However, in plots where Mulato grass, oil radish and forage sorghum were grown, a decrease in nematode populations during winter was greater $(\mathrm{P}<0.05)$ than under clean fallow. Caswell et al. (1991) observe that the use of Crotalaria juncea, Chloris gayana and Tagetes patula as inter-cycle cover crops in pineapple fields caused a reduction in the population of $R$. 
reniformis that could eventually be compared to a fallow situation. Adverse effects on nematode populations were also observed with oat (Avena sativa) cv. Hazek, sorghum (S. bicolor) cv. CSH 6, rye (Secale cereale) cv. Wren's Abruzzi and hairy vetch (Vicia sativa) cv. Chaba White (Ko \& Schmitt, 1996; Sharma et al., 1996; Gazaway et al., 2000). Our results suggest that all tested plants can be considered as good winter cover crops for $R$. reniformis suppression.

The cultivation of cotton after Mulato grass and forage sorghum yielded higher amounts of seed cotton and fiber than cotton cultivation after clean fallow (Table 3). The high fiber percentage and boll weight of cotton after Mulato grass and forage sorghum gave higher cotton fiber production after these cover crops. The number of nematodes at cotton sowing $(\mathrm{P} 2)$ and in cotton roots $[\mathrm{P} 3(\mathrm{Rr} / \mathrm{g}$ roots)], and the reproduction factor after cover crops (RFC) were negatively correlated with seed cotton yield (Table 4). From this it can be suggested that cover crops can have a significant effect on cotton yield in infested areas by decreasing $R$. reniformis population.

TABLE 2 - Soil and cotton root populations ${ }^{1}$ of Rotylenchulus reniformis $(\mathrm{Rr})$ before and after cultivation of selected cover crops during the winter

\begin{tabular}{lcccc}
\hline \hline Cover crop & $\begin{array}{c}\mathbf{P 1} \\
\mathbf{R r} / \mathbf{2 0 0} \mathbf{~ c m}^{\mathbf{3}}\end{array}$ & $\begin{array}{c}\mathbf{P 2} \\
\mathbf{R r} / \mathbf{2 0 0} \mathbf{~ c m}^{\mathbf{3}}\end{array}$ & $\begin{array}{c}\mathbf{R F C} \\
\mathbf{( P 2 / P 1 )}\end{array}$ & $\begin{array}{c}\mathbf{P 3} \\
\mathbf{R r} / \mathbf{g} \mathbf{~ r o o t}^{\mathbf{Z}}\end{array}$ \\
\hline Forage sorghum & $2,462 \mathrm{ab}$ & $960 \mathrm{ab}$ & $0.39 \mathrm{~b}$ & $266 \mathrm{ab}$ \\
Pearl millet & $1,800 \mathrm{~b}$ & $1,422 \mathrm{ab}$ & $0.79 \mathrm{ab}$ & $678 \mathrm{a}$ \\
Oil radish & $2,330 \mathrm{ab}$ & $766 \mathrm{~b}$ & $0.33 \mathrm{~b}$ & - \\
Mulato grass & $3,068 \mathrm{a}$ & $1,182 \mathrm{ab}$ & $0.38 \mathrm{~b}$ & $166 \mathrm{~b}$ \\
Clean fallow & $2,114 \mathrm{~b}$ & $1,818 \mathrm{a}$ & $0.86 \mathrm{a}$ & $771 \mathrm{a}$ \\
C.V. (\%) & 5.19 & 13.48 & 71.35 & 13.81 \\
\hline
\end{tabular}

${ }^{1} \mathrm{P} 1=29$ April 2004 (cover crops sowing); P2 = 9 November 2004 (cotton sowing); P3 = 11 January 2005 (cotton flowering); RFC = reproduction factor of the nematode after cover crops (P2/P1).

Means are average of five replications. Data followed by the same letter were not different according to LSD test at $\mathrm{P}=0.05$ based on $\log (\mathrm{x}+1)$ transformed values.

TABLE 3 - Seed and fiber cotton yields, fiber percentage and cotton boll weight after selected cover cropping in a site naturally infested by Rotylenchulus reniformis

\begin{tabular}{lcclc}
\hline \hline Cover crop & $\begin{array}{c}\text { Seed cotton } \\
\left.\text { (kg.ha-1 }^{-1}\right)\end{array}$ & $\begin{array}{c}\text { Cotton fiber } \\
\text { (kg.ha }^{-1} \text { ) }\end{array}$ & Fiber (\%) & $\begin{array}{c}\text { Boll } \\
\text { weight (g) }\end{array}$ \\
\hline Forage sorghum & $2,031^{\mathrm{z}} \mathrm{ab}$ & $1,076 \mathrm{ab}$ & $52.72 \mathrm{a}$ & $5.49 \mathrm{a}$ \\
Pearl millet & $1,931 \mathrm{bc}$ & $924 \mathrm{bc}$ & $47.87 \mathrm{bc}$ & $5.23 \mathrm{bc}$ \\
Mulato grass & $2,294 \mathrm{a}$ & $1,178 \mathrm{a}$ & $51.18 \mathrm{ab}$ & $5.40 \mathrm{ab}$ \\
Clean fallow & $1,657 \mathrm{c}$ & $751 \mathrm{c}$ & $44.96 \mathrm{c}$ & $5.12 \mathrm{c}$ \\
C.V. (\%) & 18.43 & 24.28 & 10.91 & 4.93 \\
\hline
\end{tabular}

Means are average of five replications. Data followed by the same letter were not different according to LSD test at $\mathrm{P}=0.05$.
TABLE 4 - Pearson's correlation analysis between seed cotton yield and Rotylenchulus reniformis ( $\mathrm{Rr}$ ) soil and root populations

\begin{tabular}{lcl}
\hline \hline Nematode population measured & $\mathbf{R}$ & \multicolumn{1}{c}{$\mathbf{P}$} \\
\hline $\mathrm{P} 2\left(\mathrm{Rr} / 200 \mathrm{~cm}^{3}\right)$ & -0.48 & $0.0075^{* *}$ \\
$\mathrm{RFC}$ & -0.34 & $0.0480^{*}$ \\
$\mathrm{P} 3(\mathrm{Rr} / \mathrm{g}$ roots $)$ & -0.37 & $0.0339^{*}$ \\
\hline
\end{tabular}

P2 = 5 November 2004 (cotton sowing); P3 = 11 January 2005 (cotton flowering); RFC = reproduction factor of the nematode after cover crop $(\mathrm{P} 2 / \mathrm{P} 1) ; \mathrm{R}=$ Pearson's correlation coefficient; $\mathrm{P}=$ probability; * and ** $=$ significant at 5 and $1 \%$, respectively.

Although the main benefit of the cover crops tested was reduction of soil population of $R$. reniformis, maintenance of soil moisture in no-till cover cropping practice may be another positive effect of cover crops on cotton yield. It is not unusual to observe that, even without significant suppression on $R$. reniformis populations, some cover crops may still lead to high cotton production of subsequent crops, as was observed by Gazaway et al. (2000) and Jones \& McLean (2004), using hairy vetch (Vicia villosa) and Crimson clover (Trifolium incarnatum), respectively. In these studies, nitrogen left after leguminous crops could have been the reason for high cotton yield.

Although the greenhouse experiments have demonstrated that various cover crops can reduce soil population of $R$. reniformis, field experiments are more important to evaluate the effect of cover crops on cotton yield. Mulato grass and forage sorghum in particular, used as autumn or winter cover crops in fields infested by $R$. reniformis, proved to reduce the nematode population and thereafter increase the yield of seed and cotton fiber. Different cover crops should be considered if fields have been infested by another important cotton nematode, the root-knot nematode, Meloidogyne incognita. In this case, Dias-Arieira et al. (2003) suggested that Brachiaria species should be grown as cover crop. We concluded that the use of cover crops that are non-hosts or poor hosts is an effective strategy against $R$. reniformis. This is especially adoptable in cotton fields that practice no-tillage.

\section{ACKNOWLEDGMENTS}

This research was partially supported by Fundação Agrisus - Agricultura Sustentável (Proc. 061/03).

\section{REFERENCES}

Asmus GL (2004) Ocorrência de nematóides fitoparasitos em algodoeiro no Estado de Mato Grosso do Sul. Nematologia Brasileira 28:77-86.

Birchfield W, Brister LR (1962) New hosts and nonhosts of 
reniform nematode. Plant Disease Reporter 46:683-685.

Caswell EP, Defrank J, Apt WJ, Tang CS (1991) Influence of nonhost plants on population decline of Rotylenchulus reniformis. Journal of Nematology 23:91-98.

Coolen WA, D'Herde CJ (1972) A Method for the Quantitative Extraction of Nematodes from Plant Tissue. Ghent, Belgium.State Nematology and Entomology Research Station.

Dias-Arieira CR, Ferraz S, Freitas LG, Mizobutsi EH (2003) Avaliação de gramíneas forrageiras para o controle de Meloidogyne incognita e M. javanica (Nematoda). Acta Scientiarum Agronomy 25:473-477.

Ferraz LCCB (1985) Comportamento de diversas plantas daninhas, de ocorrência comum no Estado de São Paulo, em relação ao nematóide reniforme. Nematologia Brasileira 9:143-152.

Gallaher RN, Dickson DW, Corella JF, Hewlett RE (1988) Tillage and multiple cropping system and population dynamics of phytoparasitic nematodes. Annals of Applied Nematology 2:9094.

Gazaway WS, Arkridge JR, McLean K (2000) Impact of various crop rotations and various winter cover crops on reniform nematode in cotton. Proceedings, Beltwide Cotton Conferences. San Antonio TX. January 2000. pp. 162-163.

Haramoto ER, Gallandt ER. (2005) Brassica cover cropping: I. Effects on weed and crop establishment. Weed Science 53:695701

Hutchinson JL, Jones JR, McLean KS, Willliams J (2003) Evaluation of selected cover crops to determine host suitability for Rotylenchulus reniformis. Proceedings, Beltwide Cotton Conferences. Nashville TN. January 2003. pp. 248-249.

Jenkins WR (1964) A rapid centrifugal-flotation technique for separating nematodes from soil. Plant Disease Reporter 48:692.

Jones JR, McLean KS (2004) Greenhouse and field evaluations of selected winter cover crops for reniform nematode supression in cotton. Proceedings, Beltwide Cotton Conferences, San Antonio TX. January 2004. pp. 397-399.

Ko MP, Schmitt DP 1996) Changes in plant-parasitic nematode population in pineapple fields following inter-cycle cover crops. Journal of Nematology 28:546-556.

Lal R, Yadav BS, Nandwana RP (1976) A record of some new and known weed hosts of Rotylenchulus reniformis Linford \& Oliveira, 1940 from Rajasthan. Indian Journal of Nematology 6:94-95.

Lamas FM (2007) Sistema integrado de produção do algodoeiro: fatores para redução de custos. In: Farias FJC, Rodrigues SMM, Lamas FM (Eds.) Tecnologia para o algodoeiro no Cerrado do Mato Grosso. Campina Grande PB. Embrapa Algodão. pp. 87-95.

McSorley, R (1998) Population dynamics. In: Barker KR, Pedersom, GA \& Windham GL (Eds.) Plant and Nematode Interactions. Madison, WI, American Society of Agronomy. pp. 109-133.

Oliveira MDM, Veiga Filho AA. (2002) Análise de custos e rentabilidade de alternativas de plantio direto e convencional - estudo de caso para um sistema de rotação em São Paulo SP. Revista Plantio Direto 72:19-22.

Robinson AF (2002) Reniform nematodes: Rotylenchulus species. In: Starr JL, Cook R, Bridge J (Eds.) Plant Resistance to Parasitic Nematodes. Oxon. CABI Publishing. pp. 153-174.

Robinson AF, Inserra RN, Caswell-Chen EP, Vovlas N, Troccoli A (1997) Rotylenchulus species: identification, distribution, host ranges, and crop plant resistance. Nematropica 27:127-180.

Salton JC, Fabrício AC, Hernani LC (2001) Rotação lavoura pastagem no sistema plantio direto. Informe Agropecuário 22:9299.

Sharma SB, Rego TJ, Mohiuddin M, Nageswara R (1996) Regulation of population densities of Heterodera cajani and other plant-parasitic nematodes by crop rotations on vertisols in semiarid tropical production systems in India. Journal of Nematology 28:244-251

Spehar CR, Santos RLB (2002) Quinoa BRS Piabiru: alternativa para diversificar os sistemas de produção de grãos. Pesquisa Agropecuária Brasileira 37:889-893.

Spehar CR, Teixeira DL, Cabezas WARL, Erasmo EAL (2003) Amaranto BRS Alegria: alternativa para diversificar os sistemas de produção. Pesquisa Agropecuária Brasileira 38:659-663.

Starr JL (1998) Cotton. In: Barker KR, Pedersom GA, Windham GL (Eds.) Plant and nematode interactions. Madison WI. American Society of Agronomy. pp. 359-380.

Zancanaro L, Tessaro LC (2006) Manejo e conservação do solo. In: Moresco E (Ed.) Algodão: pesquisas e resultados para o campo. Cuiabá MT. Facual. pp. 36-55. 